\title{
Realisme Magis di Pesantren Darussalam Ciamis
}

\author{
Faruk, Cahyaningrum Dewojati, Fadil Munawwar Manshur, Asef Saeful Anwar \\ Fakultas Ilmu Budaya, Universitas Gadjah Mada \\ Korespondensi: farukkhan@ugm.ac.id
}

\begin{abstract}
Nowadays magical Realism is the most popular literary genre in the world. This genre has strong influences in literature as well as fine art and film. It is for this reason that people competence in working with this genre is very important for developing Indonesian creative industry. Therefore, Magister Program for Literary Studies Faculty of Cultural Sciences Gadjah Mada University necessities to have a workshop program for investing people writing capability in this kind of genre. Target subject for the program is Darussalam Literary Community whose activities located in Islamic Boarding House (Pesantren) Darussalam, Ciamis, West Java. By using theory of Magical Realism and participatory method in three days intensive course the program found that the member of community involved in the course had strong potential capacity in literary writing. Although the first step of the program focused in training for writing in realistic literary work, there was a surprising phenomenon indicated the participant capability in writing magical realist work as well.
\end{abstract}

Keywords: Magical realism; pesantren; literature

\begin{abstract}
Abstrak
Realisme magis merupakan genre sastra yang saat ini paling populer di dunia. Paham ini tidak hanya berpengaruh di bidang seni sastra, tetapi juga seni rupa, film, dan sebagainya. Oleh karena itu, kemampuan untuk menulis karya sastra dengan genre ini sangat penting bagi industri kreatif. Dengan alasan inilah, Program Magister Ilmu Sastra, Fakultas Ilmu Budaya UGM menganggap perlu untuk mengadakan pelatihan penulisan sastra realisme magis ini bagi masyarakat. Yang dipilih sebagai kelompok sosial sasaran adalah Komunitas Sastra Darussalam yang berlokasi di Pesantren Darussalam Ciamis. Tahap pertama program ini adalah pelatihan dasar penulisan sastra dengan genre realisme yang juga menjadi dasar dari realisme magis. Program itu dilaksanakan secara intensif selama tiga hari dengan menggunakan teori realisme magis sebagai kerangka konseptualnya dan gabungan antara ceramah, diskusi, latihan, dan partisipasi sebagai metodenya. Hasil kegiatan tersebut membuktikan bahwa peserta pelatihan yang berjumlah 15 orang mempunyai kepekaan terhadap persoalan-persoalan empiris yang ada di lingkungan pesantren dan mempunyai kemampuan dalam penulisan latar, tokoh, serta alur cerita. Meskipun program pada tahap ini difokuskan pada penulisan karya sastra yang realistis, peserta sudah memperlihatkan potensi dalam penulisan realisme magis.
\end{abstract}

Kata kunci: Realisme magis; pesantren; sastra

\section{Pendahuluan}

Dalam rangka pelaksanaan Tri Darma Perguruan Tinggi, pada tahun 2019, Program Studi Magister Sastra, Departemen Bahasa dan Sastra, Fakultas Ilmu Budaya, Universitas Gadjah Mada telah menyusun sejumlah program kerja yang berkaitan dengan penelitian, pendidikan, dan pengabdian kepada masyarakat. Salah satu program kerja dalam 
bidang pengabdian pada masyarakat oleh Program Studi Magister Sastra UGM adalah "Pelatihan Penulisan Karya Fiksi di Komunitas Sastra Darussalam, Ciamis, Jawa Barat”. Pada kesempatan ini, program kerja tersebut dilaksanakan oleh Program Studi Magister Sastra UGM bekerja sama dengan Komunitas Sastra Darussalam (KSD), sebuah komunitas sastra di lingkungan Pondok Pesantren Darussalam, Ciamis, Jawa Barat. Komunitas ini didirikan atas kesamaan visi, misi, dan semangat Keluarga Besar Pesantren Darussalam dan civitas academica IAID (Institut Agama Islam Darussalam) Ciamis untuk membangun tradisi kegiatan bersastra di lingkungan komunitas pesantren. Anggota KSD terdiri atas santri, mahasiswa, guru, dosen, dan anggota masyarakat yang memiliki kepedulian, perhatian, dan kecintaan pada dunia penulisan.

Sebenarnya, Prodi Magister Sastra, FIB, UGM, sudah melakukan beberapa kali kegiatan pelatihan untuk sebuah komunitas sastra di Yogyakarta, yaitu komunitas Stube-Hemat. Meskipun demikian, kegiatan kali ini memperlihatkan kekhususan dalam tiga hal. Pertama, kegiatan pelatihan akan menjadi program kerja sama yang berjangka panjang dan berkesinambungan, atas dasar MOU, sehingga dapat terusmenerus dikembangkan dan dimonitor perkembangannya sampai dengan diperoleh hasil yang maksimal. Kedua, program ini juga merupakan program yang akan sangat terintegrasi dengan dua darma universitas yang lain, yaitu pendidikan/pengajaran dan penelitian, yang akan menjadi prioritas prodi, yaitu realisme magis. Ketiga, sehubungan dengan yang kedua, kegiatan ini akan memusatkan diri pada pelatihan penulisan karya-karya sastra yang bergenre realisme magis sebagai sebuah genre sastra yang saat ini sangat populer dan representatif bagi perkembangan peradaban global mutakhir karena memadukan kode sosial-budaya dan literer yang positivistik, modernis, dan realistik dengan kode sosial yang fenomenologis, pramodernis, dan magis. Kekhususan yang ketiga inilah yang membuat kegiatan ini memilih lingkungan pesantren di sebuah daerah yang relatif terpencil, yang di dalamnya berlangsung kehidupan budaya yang tidak hanya bersifat keagamaan, tetapi juga bersifat tradisional atau pramodern.

Sebagai sebuah genre yang mempertemukan dua kode kebudayaan, yaitu antara yang positivistik serta modernis dan yang fenomenologis, pramodern, serta realisme magis (Faris, 2004), memberi peluang besar bagi masyarakat dengan kebudayaan tradisional dan yang berbasis keagamaan, seperti yang ada dalam lingkungan pesantren Darussalam, untuk terlibat atau berpartisipasi penuh. Hal itu disebabkan oleh adanya kenyataan bahwa di dalam lingkungan tersebut tersimpan potensi kekayaan budaya, baik mitos, legenda, maupun kepercayaan pada hal-hal yang magis. Dengan pelatihan ini, diharapkan agar pengetahuan mengenai genre sastra realisme magis pada tataran global dapat dimanifestasikan, diangkat ke permukaan, dan diwujudkan dalam bentuk karya-karya sastra yang dapat diterima dalam lingkungan sastra yang lebih luas, baik dalam tataran nasional maupun global. Lebih jauh lagi, mengingat realisme magis merupakan sebuah paham kesusastraan yang sangat populer, yang bahkan telah benyak memasuki lingkungan industri kreatif seperti film, seni rupa, desain, fotografi, dan sebagainya (Bowers, 2004), pengangkatan potensi lingkungan pesantren Darussalam di atas menjadi manifes berupa karya-karya sastra, dapat sekaligus berarti pengangkatannya ke dalam kancah industri kreatif yang sekarang ini menjadi salah satu program unggulan pemerintah Indonesia dalam menghadapi persaingan global (Saedah, 2019). 


\section{Pedekatan Pelaksanaan Program}

Kerangka konseptual yang digunakan di dalam pengabdian ini didasarkan pada pendekatan hermeneutik, yang mengasumsikan bahwa pengetahuan adalah sebuah apropriasi dari yang asing menjadi yang dikenal atau familier (Saukko, 2003). Dengan demikian, kerangka konseptual pengabdian ini berangkat dari asumsi mengenai kedekatan kultural antara objek pengetahuan dan subjeknya. Karena objek pengetahuannya adalah genre sastra realisme magis yang merupakan percampuran antara yang positivistik dan fenomenologis, modernis dan pramodern, yang rasional dan yang irasional, yang realistik dan magis, subjek pengetahuan yang dipilih adalah para santri yang hidup dalam lingkungan sistem pendidikan pesantren yang menerapkan sekaligus ilmu pengetahuan modern yang berbasis pengalaman empiris dan rasional dengan ajaran-ajaran keagamaan yang berbasis keimanan.

Baik menurut Faris (2004) maupun Bowers (2004), karya realisme magis adalah karya yang memadukan dua cara pemahaman yang bertentangan mengenai kehidupan, yaitu yang disebut sebagai kode realistik dan kode magis, dalam posisi yang seimbang dalam pengertian tidak menihilkan satu sama lain. Karena realisme magis merupakan sebuah genre baru yang muncul sejak pertengahan abad XX, persisnya sejak tahun 1955, sebagai sebuah genre alternatif bagi genre sastra yang sebelumnya hegemonik, pengabdian ini dimulai dengan pelatihan mengenai aspek realisme dari genre tersebut.

Ian Watt (1987) mengatakan bahwa realisme dalam sastra bukanlah menyangkut apa yang digambarkan, melainkan cara penggambarannya. Karya sastra realis, menurutnya, berusaha menggambarkan lingkungan hidup yang partikular, yang ada dalam ruang dan waktu tertentu, yang karenanya dianggap dapat dialami dan diverifikasikan dalam kehidupan keseharian manusia. Sejalan dengan karakteristik lingkungan yang demikian, manusia-manusia yang digambarkan pun adalah manusia-manusia yang partikular, orang biasa, yang dapat ditemukan dalam lingkungan keseharian, bukan manusia yang bersifat tipologis yang karenanya universal. Karakteristik yang demikian sesuai dengan kecenderungan peradaban modern yang melahirkan karya-karya realis itu, yaitu peradaban yang berbasis ilmu pengetahuan positif, empiris, dan sekaligus rasional. Oleh sebab itu, sesuai dengan prinsip rasionalisme, cerita dalam karya realis harus merupakan sebuah sistem yang terpadu, membentuk suatu keutuhan, dengan jalan cerita yang tersusun secara kausal. Dengan demikian, pengabdian ini akan memberikan pelatihan mengenai tiga aspek dari karya sastra realistik, yaitu (1) aspek latar, lingkungan pengalaman, atau kehidupan yang partikular, (2) pembentukan tokoh atau karakter yang juga partikular, dan (3) penyusunan plot atau alur cerita yang rasional atau logis.

\section{Pelaksanaan Program}

\section{Lokasi dan Subjek Pengabdian}

Sesuai dengan kerangka konseptual yang sudah dikemukakan, pengabdian ini diadakan di sebuah pesantren yang mempunyai karakteristik yang dianggap sesuai dengan objek pengetahuan dan keterampilan yang diberikan, yaitu Pesantren Darussalam Ciamis (PPDC). Pesantren tersebut terletak di Desa Dewasari, Kecamatan Cijeungjing, Kabupaten Ciamis, Jawa Barat sebelah timur. Jarak dari ibu kota Ciamis ke pesantren 


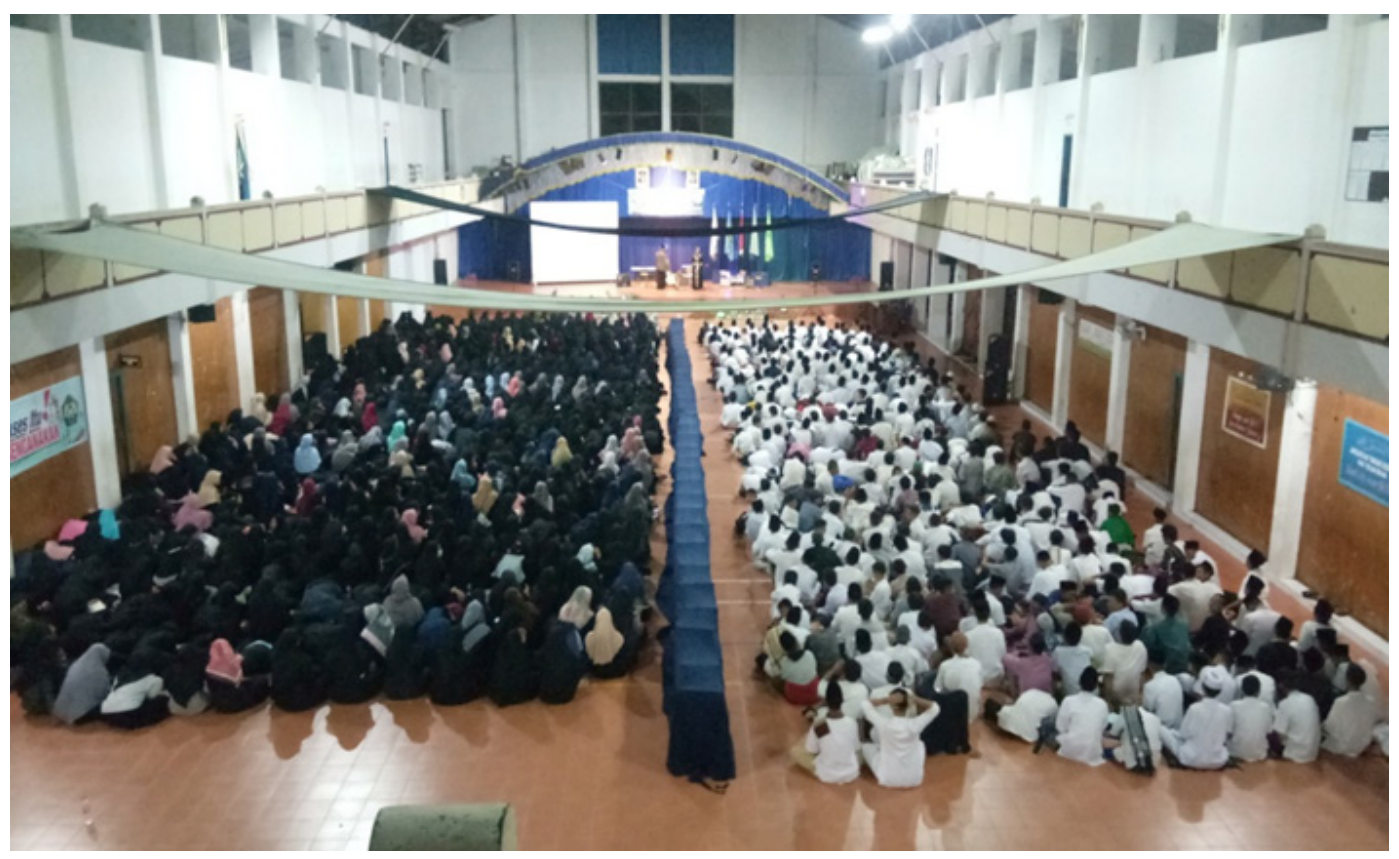

Gambar 1. Pembukaan kegiatan PKM UGM-KSD di Aula Ponpes Darusalam Ciamis.

tersebut hanya $5 \mathrm{~km}$. Jarak dari kota Banjar adalah sejauh $22 \mathrm{~km}$ ke sebelah barat. Mayoritas penduduk desa tersebut beragama Islam dengan tradisi Nahdliyyin. Sesuai dengan tradisi tersebut, mereka biasa melakukan upacara tahlilan sebagai upacara selamatan bagi orang yang meninggal, yang diselenggarakan pada peringatan hari ketujuh, keempat puluh, keseratus, dan keseribu. Selain itu, mereka juga biasa membaca selawat Barzanji pada peringatan hari-hari besar Islam. Yang tidak kalah pentingnya adalah adanya tradisi berkesenian dan berkesusastraan yang khas dan kreatif di dalamnya.

Pesantren ini dihuni oleh 4.000-an santri, dari tingkat sekolah dasar, menengah, hingga tingkat perguruan tinggi. Mayoritas santri berasal dari Jawa Barat dan Jabotabek (Jakarta, Bogor, Tangerang, Bekasi), dengan latar belakang tradisi keagamaan yang sama dengan masyarakat setempat. Pesantren Darussalam mempunyai tradisi kenahdliyyinan yang khas, yaitu yang berupa upacara pembacaan Salawat Nurdah yang dilakukan oleh ribuan santri seminggu sekali, tepatnya pada setiap malam Ahad. Selawat ini berisi cerita tentang sejarah perjuangan Nabi Muhammad SAW dalam dakwah Islamnya kepada masyarakat Arab Quraisy.

Kabupaten Ciamis adalah sebuah kabupaten di Provinsi Jawa Barat, Indonesia. Ibu kotanya adalah Ciamis Kota. Kabupaten ini berada di bagian tenggara Jawa Barat, berbatasan dengan Kabupaten Majalengka dan Kabupaten Kuningan di utara, Kabupaten Cilacap (Jawa Tengah) dan Kota Banjar di timur, Kabupaten Pangandaran di selatan, serta Kota Tasikmalaya dan Kabupaten Tasikmalaya di barat. Kabupaten ini terdiri atas 27 kecamatan, yang dibagi lagi menjadi sejumlah desa dan kelurahan. Baik atas dasar sejarah maupun legenda, Kota Ciamis banyak dikaitkan dan bahkan dipercaya oleh masyarakatnya pernah menjadi pusat Kerajaan Galuh yang bertradisi Hindu-Buddha. Di daerah ini masih dapat ditemukan sebuah komunitas pra-Islam yang menamakan diri sebagai "Sunda Buhun". 
Dengan karakteristik tersebut tampak bahwa para santri dan ustaz yang menjadi subjek pengabdian dari program ini beserta karakteristik lingkungan kehidupannya memang sangat memenuhi syarat untuk kegiatan pengabdian ini. Pertama, lokasinya relatif terpencil, terjepit di antara dua kota provinsi, yaitu Jawa Barat dan Daerah Istimewa Yogyakarta. Kedua, masyarakat dan kebudayaannya mempunyai potensi kekayaan tradisi yang beraneka, yaitu Islam, tradisi Hindu-Buddha, dan lingkungan pendidikan modern.

\section{Metode}

Pelatihan dilakukan dengan gabungan metode ceramah, diskusi, pelatihan, dan partisipasi, dengan dua orang sastrawan yang bereputasi nasional, yaitu Abidah Al Khaleiki dan Mahfud Ikhwan, serta seorang dosen muda yang aktif dalam penulisan kreatif, yaitu "Asef" Saeful Anwar sebagai narasumber dan pendampingnya. Kegiatan dimulai dengan ceramah teoretik dan pembagian pengalaman para narasumber, dilanjutkan dengan diskusi dan pelatihan dengan cara memberikan kebebasan kepada peserta untuk memilih topiknya masing-masing, yang hasilnya kemudian dipresentasikan dalam kelompok, didiskusikan kembali, dan akhirnya diperbaiki serta dikembangkan. Kegiatan pelatihan yang pertama adalah meminta peserta untuk memilih dan mendiskusikan apa yang dinamakan ide pokok. Sesuai dengan kerangka konseptual yang dipakai, penetapan ide pokok ditentukan oleh partikularitasnya dan kedekatannya dengan lingkungan kehidupan setempat. Setelah mendapat komentar dari sesama peserta dan narasumber, peserta melakukan pengembangan terhadap ide pokok tersebut hingga menjadi sebuah cerita mini.

\section{Refleksi Capaian Program}

Setelah dilakukan pelatihan di atas, melalui proses dan metode yang sudah ditetapkan, diperoleh hasil sebanyak 42 ide pokok dan 19 cerita mini dari 14 orang peserta. Keseluruhan ide pokok tersebut dapat dilihat dari tabel di bawah ini.

Tabel 1. Ide Pokok

\begin{tabular}{|c|c|c|}
\hline NO & NAMA & IDE POKOK \\
\hline \multirow{3}{*}{1.} & \multirow{3}{*}{ Ai Siti Salamah } & Kabur dari pesantren dengan jalan kaki \\
\hline & & Kehabisan bekal ketika ikut ziarah ke makam Pamajihan \\
\hline & & Jatah lauk makan dengan daging ayam \\
\hline \multirow{3}{*}{2.} & \multirow{3}{*}{ Yani } & Didenda ketika kesiangan \\
\hline & & Kabur saat hafalan \\
\hline & & Nangis bersama \\
\hline \multirow[t]{2}{*}{3.} & Yogi Pratama & $\begin{array}{l}\text { Mendapat uang jajan tanpa di beri orang } \\
\text { tua caranya diundang ngaji }\end{array}$ \\
\hline & & $\begin{array}{l}\text { Suka senang kalau ada pengumuman ada } \\
\text { orang yang mati karena ada proyek tahlilan }\end{array}$ \\
\hline
\end{tabular}




\begin{tabular}{|c|c|c|}
\hline \multirow{3}{*}{4.} & \multirow{3}{*}{ Laily Nafisah Maharani } & Lomba MFQ \\
\hline & & Tashih 5 juz Al-Quran dan Imrithy \\
\hline & & Lomba pidato Bahasa Arab dengan "dia \\
\hline \multirow{3}{*}{5.} & \multirow{3}{*}{ Deni Ahmad Fauzi } & $\begin{array}{l}\text { Berdiri tegak di tengah lapang ketika } \\
\text { senja mulai terbenam sambil mengatakan } \\
\text { "ana ahsuy hatta khomaah" }\end{array}$ \\
\hline & & Anak Pesantren \\
\hline & & Takbir menyeru \\
\hline \multirow{3}{*}{6.} & \multirow{3}{*}{ Akke Prawira } & Molornya kesadaran \\
\hline & & Tatanan sepak bola \\
\hline & & Ustadz horor \\
\hline \multirow{3}{*}{7.} & \multirow{3}{*}{ Adytya Maulaka Aziz } & Kolam ikan di depan ponpes \\
\hline & & Alarm Pak Kyai \\
\hline & & Bisul yang membawa perkara \\
\hline \multirow{3}{*}{8.} & \multirow{3}{*}{ M.N. Husain K. } & Tampil nasyid \\
\hline & & Kehilangan sendal \\
\hline & & Dimarahin pemimpin \\
\hline \multirow{3}{*}{9.} & \multirow{3}{*}{ Fauzan Badru Tamam } & Api sejarah dalam pertemuan pertama \\
\hline & & Surat kaleng sebagai kendaraan rasa \\
\hline & & Sang pemimpi \\
\hline \multirow{3}{*}{10.} & \multirow{3}{*}{ Pahrur Rohim } & Pulang pergi sandal kesayangan \\
\hline & & Nyuci baju pukul 02.00 pagi \\
\hline & & Susah diet \\
\hline \multirow{3}{*}{11.} & \multirow{3}{*}{$\begin{array}{l}\text { MuhammadRifda } \\
\text { Saygidan Murtadho }\end{array}$} & Baru awal bulan cair \\
\hline & & Tampil di gedung NU \\
\hline & & Hilangnya barang kesayangan \\
\hline \multirow{3}{*}{12.} & \multirow{3}{*}{ Nur Fatihah Najmi } & Pertama kali ngaji kitab kuning \\
\hline & & Mengikuti lomba FLS2N \\
\hline & & Suka sama kakak kelas \\
\hline \multirow{3}{*}{13.} & \multirow{3}{*}{ Sofyan Walidin Hanif } & Meninggalkan tempat perjuangan \\
\hline & & Mancing mania di kolam Pak Ustadz \\
\hline & & Kobong bintang lima \\
\hline \multirow{3}{*}{14.} & \multirow{3}{*}{ Fikri } & Makan bareng beserta santri \\
\hline & & Gundul rambut seluruh santri \\
\hline & & Mandi bareng di kamar mandi yang satu \\
\hline
\end{tabular}

Tabel tersebut menunjukkan kepekaan para peserta terhadap berbagai peristiwa yang terjadi di sekitar pesantren, sebuah dunia penghayatan yang mereka hidupi dan sekaligus menghidupi mereka. Yang banyak dimunculkan adalah peristiwa yang berkaitan dengan keterkejutan budaya ketika mereka mulai menjadi anggota pesantren dengan segala macam proses adaptasi dengan lingkungan yang baru. Pengalaman pertama mengaji kitab kuning, sandal yang hilang, sulitnya menyesuaikan diri dengan ritme pesantren seperti masalah tidur dan sejenisnya, persoalan kesulitan keuangan, dan sebagainya. Hal lain yang juga terekam dalam memori mereka adalah kesenangan yang diperoleh 
dalam mengisi waktu luang seperti bermain sepak bola dan memancing serta tampil di panggung untuk bermain musik.

Begitu ide-ide pokok itu direalisasikan, mulai lebih jelaslah potensi-potensi kesastraan mereka, baik dari segi bahasa, membentuk karakter, menggambarkan latar cerita, maupun menjalin jalan cerita. Sebagai contoh dapat dilihat kutipan berikut.

"Saat pertama kali masuk pesantren, suasananya sangat jauh berbeda dengan suasana di rumah. Asrama pesantren kurang dijaga kebersihannya. Sehingga malam pertama di pesantren, hampir semua santri baru mengalami susah tidur. Namun ada juga yang memang ingin sekali mesantren.

Ketika melihat keadaan pesantren seperti itu, ada beberapa santri baru yang menangis, karena ia memang terpaksa masuk pesantren. Ia menangis sampai adzan subuh berkumandang. Matanya sangat sembab dan hidungnya merah.”

Kutipan di atas menggambarkan potensi yang bagus dari penulisnya dalam menggambarkan suasana dan membentuk karakter tokoh. Meskipun cerita itu sangat pendek, di dalamnya sudah tergambar latar pesantren dengan lingkungannya yang kurang bersih dan irama kehidupannya yang banyak melakukan kegiatan pada malam hari. Berbagai karakter dari santri dalam menyikapi kehidupan pesantren, terutama yang terkait dengan motivasi mereka, juga tergambar. Ada yang mengalami kesulitan beradaptasi hingga menjadi susah tidur, ada yang berniat kuat masuk pesantren sehingga tidak mengalami masalah dengan perubahan lingkungan dan gaya hidup, dan ada juga yang menangis.

"Tepat sedang dibangku SMP, saat sedang di pondok pesantren yang sudah jauh dari manjaan ayah-bunda. Mulai hidup sederhana, saat musim pengiriman dari orang tua tidak cair. Terlintas dalam pikiranku untuk berpacaran dengan orang kaya raya di pondok putra itu. Entah melodi apa yang mengantarkan kita dipertemukan dikantin pesantren. Saat itu sedang tidak punya uang sepeser pun. Akhirnya aku jadian dengan mojang garut yang kaya.

Siang hari amat panas, kubuka pintu kulkas miliki seorang ibu kantin pesantren. Kemudian diambilkanlah minuman dingin ale-ale lalu meminta pacar baruku untuk membayar semua jajanan yang aku ambil tadi. Dengan senang hati dia membayarkan jajanan. Namun entah angin apa, yang terlintas dalam telingaku, mulutku tiba-tiba menjatuhkan semua harapan yang beliau percayakan. Aku mengajak "PUTUS" pada pacar baruku. Dia langsung lari ke pondok putra, Bingung!!!

Tiba-tiba 10 menit kemudian ada teman pacar baruku, beliau mengadu, kalau esok Idrus (pacar baruku) akan pulang ke Garut dengan alasan dia sangat sakit hati atas perlakuanku padanya. Keesokan harinya ada ayah bundanya menjemput beliau, menarik dari pesantren itu, dibereskanlah semua barang-barangnya ke dalam mobil, dan aku sangat menyesal.”

Kekuatan penulis dalam kutipan yang kedua di atas terletak terutama pada pembangunan alur ceritanya. Karena mengalami kesulitan ekonomi, tokoh cerita berharap dan akhirnya mendapatkan seorang pacar yang bisa membantunya dalam mengalami kesulitan tersebut, pacar yang terbilang kaya atau berada seperti yang ia inginkan. Namun, mungkin merasa tidak pantas untuk dilakukan di pesantren atau karena merasa salah telah melakukan hubungan cinta dengan alasan ekonomi, si tokoh 


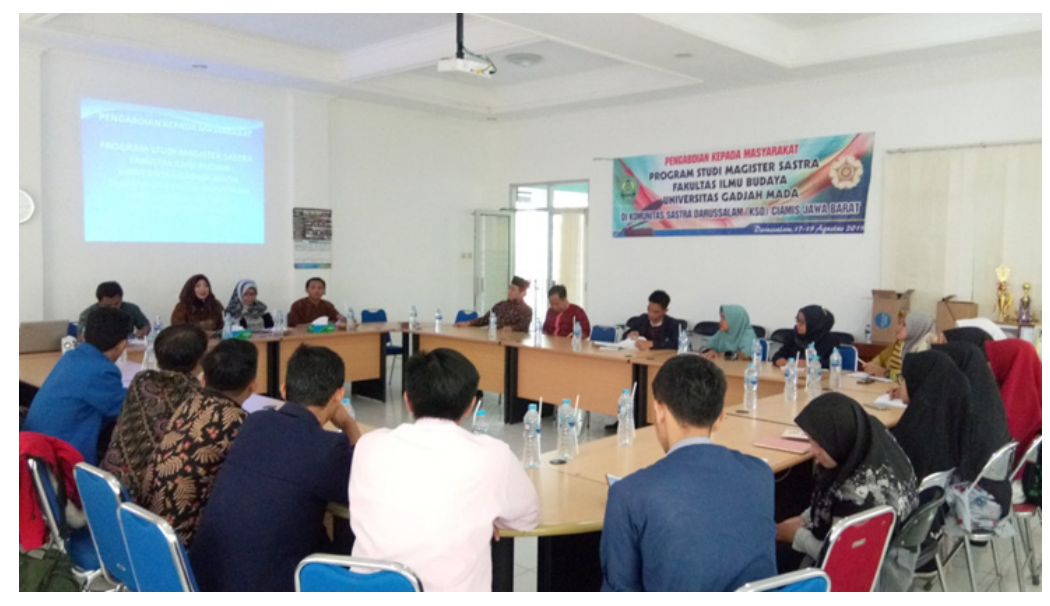

Gambar 2. Pelatihan Penulisan Karya Fiksi di R. Sidang IAID Darussalam

begitu saja memutuskan pacar barunya itu. Akan tetapi, cerita ternyata belum berakhir. Akibat keputusannya tersebut, si pacar menjadi sakit hati sehingga memutuskan untuk keluar dari lingkungan pendidikan keagamaan itu. Cerita berakhir dengan penyesalan tokoh cerita akibat kehilangan pacarnya tersebut.

Namun, sesungguhnya, tidak hanya penyusunan alur yang menjadi kekuatan cerita mini di atas, tetapi juga penggambaran latar dan pembentukan karakter. Bahkan, gambaran latar dalam cerita di atas terlihat amat rinci tanpa menjadi deskripsi yang kaku. Gambaran mengenai kulkas dan tindakan tokoh mengambil minuman yang ada di dalamnya, misalnya, merupakan rincian yang menarik karena sekaligus menggambarkan harapan atau perasaan si tokoh yang sudah lama merindukan minuman itu. Tokoh dengan imajinasi yang aneh, yang menemukan jalan penyelesaian yang juga mengejutkan, tidak biasa, merupakan karakter yang tidak kalah menarik.

Gambaran plot yang tidak kalah menariknya, dengan gaya bercerita yang lincah dan sedikit bumbu humor, terdapat dalam cerita "Ditinggalkan di Masjid..”. Gambaran yang ironis mengenai kepercayaan bahwa orang kesurupan adalah akibat dari kemasukan roh halus, yang disertai dengan pikiran yang "liar", terlihat dalam kutipan di bawah ini.

"Semenjak aku mengobati orang kesurupan dengan membacakan pancasila. Kepercayaanku terhadap orang kesurupan jadi sadar, aku meyakini suatu hal orang kesurupan itu bukanlah karena kemasukan siluman, pocong, dll. Akan tetapi hanya gangguan emosi dan kemarahan yang meluap.

Aku sering menyembuhkan orang kesurupan dengan perlakuan yang tulus dan membisikkan pada orang yang sedang kerasukan itu "ah hanya marah, kau bukan setan, ah hanya marah, jadi menangislah! Tak apa menangislah! Kau akan baikbaik saja!"

Dan percaya atau tidak orang itu alhamdullilah sembuh."

Kutipan selanjutnya memperlihatkan kemampuan dari menggambarkan dengan relatif rinci semacam monolog batin tokoh.

"Jam pelajaran pertama sebentar lagi akan berakhir dan akan diganti dengan pelajaran berikutnya. Rasa bosan menghinggap serta rasa kantuk yang tak tertahankan. 
Berulang kali aku coba menghilangkan rasa kantukku tetap saja tak bisa. Meski saat bel berbunyi menandakan telah berakhir jam pelajaran pertama sungguh benar-benar setan dalam mataku tak kanjung pergi. Sebelum ustadz/guru masuk menggantikan ustadz yang pertama mengajar, aku mencari kesempatan melihat dari jendela ke arah gerbang. Seakan syaithan mendukungku, aku meminta izin kepada ketua kelas untuk izin ke toilet, padahal niat awalnya untuk kabur."

Semua data di atas menunjukkan potensi para santri, khususnya peserta pelatihan, dalam penulisan karya sastra yang bergenre realis. Mereka tampaknya hanya membutuhkan sedikit sentuhan untuk dapat membuat sebuah cerita pendek yang utuh dengan genre yang sama. Kemampuan mereka dalam membangun latar, karakter, dan jalan cerita, hanya dalam waktu yang singkat, dengan cerita yang minim, sudah dapat dilihat. Begitu juga kepekaan mereka dalam menangkap dan mengartikulasikan dunia pesantren sebagai dunia penghayatan yang menghidupi dan dihidupi para peserta. Di antara cerita mengenai peristiwa-peristiwa yang realistis di atas, terdapat satu cerita yang mengandung pengalaman magis sebagai bahan, yaitu cerita tentang orang-orang yang kesurupan. Cerita tersebut membuka sebuah kenyataan yang sesuai dengan realisme magis, yaitu bahwa hal-hal yang magis ternyata bukanlah hal yang luar biasa, yang jauh dari kehidupan keseharian, melainkan bagian dari dunia pengalaman mereka. Hanya saja, dan mungkin akibat dari pendekatan yang diminta adalah pendekatan realistik, kesurupan itu dilihat dari perspektif realisme, yaitu dihadirkan untuk tidak dipercaya.

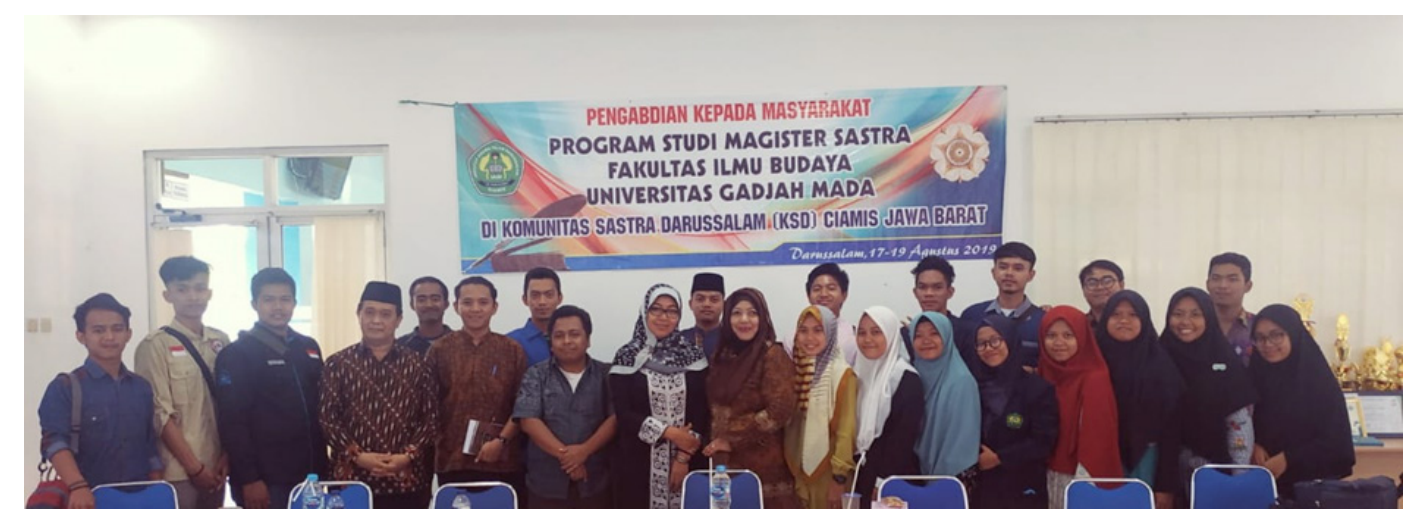

Gambar 3. Narasumber, Tim PKM, besrta peserta "Pelatihan Penulisan Karya Fiksi"

\section{Penutup}

Hasil penelitian berbasis pengabdian kepada masyarakat ini menunjukkan dan mengukuhkan dugaan awal, yaitu bahwa masyarakat pesantren, khususnya yang berada di Pesantren Darussalam, Ciamis, merupakan lahan yang tepat bagi penyemaian kemampuan menulis karya sastra dengan genre realisme-magis. Data-data yang sudah dipaparkan dapat menunjukkan bahwa prasyarat pertama, yaitu kemampuan menulis karya sastra bergenre realis, sudah dapat dikatakan terpenuhi dan kemampuan menangkap serta mengartikulasikan peristiwa dan pengalaman magis juga sudah muncul secara otomatis, tanpa direncanakan. Karena program pengabdian ini merupakan sebuah program jangka panjang, atas dasar kerja sama antara UGM dan Pesantren Darussalam, 
pelatihan kedua tampak memberi harapan besar. Dalam pelatihan kedua yang akan dilakukan pada tahun 2020, perhatian masih dipusatkan pada kemampuan menulis karya sastra dengan genre realistik. Hanya, pelatihan itu tidak lagi hanya diarahkan pada kemampuan membuat gagasan pokok dan pengembangannya menjadi sebuah cerita mini, tetapi pada pengembangannya menjadi sebuah cerita pendek yang utuh, dengan kualitas yang memadai untuk dipublikasikan.

\section{Daftar Pustaka}

Bowers, M. A. (2004). Magical Realism. London and New York: Routledge.

Fariz, W. B. (2004). Ordinary Enchantment: Magical Realism and Demystification of Narrative. Nashville: Vanderbilt University Press.

Saedah, E. (2019). "Industri Kreatif Masih Potensial”, Suara Karya. 8 Agustus 1019. Jakarta.

Watt, I. (1986). The Rise of the Novel: Studies on Defoe, Richardson, and Fielding. California: University of California Press. 